\title{
Fluvial environmental disasters: risk perception and evaluation of government responses by riverine populations in Cacau Pirêra, Iranduba/AM
}

Desastres ambientais fluviais: percepção de risco e avaliação de respostas governamentais por populações ribeirinhas em Cacau Pirêra, Iranduba/AM

David Franklin da Silva Guimarães ${ }^{\mathrm{a}}$

Camila dos Santos Belmirob

Mônica Alves de Vasconcelos ${ }^{c}$

Henriques dos Santos Pereira ${ }^{d}$

aMestre pelo Programa de Pós-Graduação em Ciências do Ambiente e Sustentabilidade na Amazônia, Universidade Federal do Amazonas - UFAM, Manaus, AM, Brasil.

E-mail: davidguimaraes@ufam.edu.br

${ }^{b}$ Universidade Federal do Amazonas, Manaus, AM, Brasil E-mail: ca.belmiro15@gmail.com

'Mestre em Ciências Florestais e Ambientais pela Universidade Federal do Amazonas - UFAM,

Manaus, AM, Brasil.

E-mail:monica.engbio@gmail.com

${ }^{d}$ Doutor em Ecologia pela Pennsylvania State University, Professor titular do Programa de PósGraduação em Ciências do Ambiente e Sustentabilidade na Amazônia, Universidade Federal do Amazonas - UFAM, Manaus, AM, Brasil.

E-mail: hpereira@ufam.edu.br

doi:10.18472/SustDeb.v10n3.2019.23711

Received: 16/03/2019

\section{ABSTRACT}

This article unveils the perceptions of vulnerable populations of the Amazon regarding the risks of river disasters and highlights their assessment of the effectiveness of government responses. The record of 
perceptions, assessments and identification of social vulnerabilities were obtained in interviews with focus groups formed by residents of Cacau Pirêra, in the Amazon. To characterize the environmental threats and vulnerabilities, fluviometric and altimetric data of the occupied areas were used. In that District, floods do not have to exceed normal limits to constitute environmental disasters and, in the perception of residents, pose more risks than ebb. Participants point to the low effectiveness of public policies as the main cause of the ineffectiveness of the government's response to water disasters. Natural disaster studies should consider the interactions between the environmental and social aspects of territories to reach an understanding of the complexity of the context in which they occur.

Keyword: Socio-environmental vulnerability. Sociology of disasters. Extreme events. Socioecological systems. Flood. Resilience.

\section{RESUMO}

Este artigo desvela as percepções de populações vulneráveis da Amazônia quanto aos riscos de desastres fluviais e evidencia a avaliação que fazem quanto à eficácia das respostas do poder público. O registro das percepções e avaliações e a identificação das vulnerabilidades sociais foram obtidos em entrevistas com grupos focais formados por moradores de Cacau Pirêra, no Amazonas. Para caracterização das ameaças e vulnerabilidades ambientais foram utilizados dados fluviométricos e altimétricos das áreas ocupadas. Naquele Distrito, as inundações não precisam ultrapassar os limites de normalidade para se configurarem como desastres ambientais e, na percepção dos moradores, representam mais riscos que as vazantes. Os participantes apontam a baixa efetividade das políticas públicas como principal causa da ineficácia da resposta do poder público aos desastres fluviais. Os estudos de desastres naturais devem considerar as interações entre os aspectos ambientais e sociais dos territórios para alcançarem um entendimento acerca da complexidade do contexto em que ocorrem.

Palavras-Chave: Vulnerabilidade socioambiental. Sociologia dos desastres. Eventos extremos. Sistemas socioecológicos. Inundação. Resiliência.

\section{INTRODUCTION}

Although the concept of disasters recognized as natural ones may still arouse debate in academia (MATTEDI, 2017), in Brazil, such disasters are considered by law as a result of adverse natural or man-made events on a vulnerable ecosystem causing human, material or environmental damage and consequent economic and social damages (BRAZIL, 2010). The inherent complexity of these disasters does not allow them to be defined as natural but rather as environmental disasters.

The occurrence of environmental disasters is not only linked to the natural hazards arising from hurricanes, earthquakes, volcanic eruptions, floods and ebb, since such disasters are intrinsically related to the vulnerability of affected populations (HUMMEL et al., 2016). Vulnerability, in the case of climate change, is the inability of populations to cope with the impacts caused by extreme events, because of their social situation and environmental condition (ROSA and MALUF, 2010).

In the sociology of disasters, human components are crucial for understanding the complexity of event-related factors. Thus, an important aspect to consider in disaster studies is the residents' perception of risk. Risk perception is related to disasters and is influenced by a group of interrelated factors that include past experiences, current attitudes toward the event, personality and values, along with future expectations (COÊLHO, 2007). Considering the risk perception of vulnerable communities and their determining factors, including the type of disaster itself, is essential for improving risk communications and designing effective mitigation policies (HO et al., 2008). 
Still considering the human dimension of disasters, it is paramount for guidance to decision-making processes to take into account the understanding of the vulnerability of risk-prone populations. Vulnerability demonstrates the unsustainability of the development model that generates environmental injustices by forcing the population to live in risk areas. Areas of risk and environmental degradation are often areas of poverty (ALVES, 2006). Thus, disasters considered natural, in most situations, should be treated as environmental disasters, that is, whose causes are not only of "natural" causes and independent of anthropic actions.

The aggravation of environmental disasters has as its main causes: incorrect land occupation, ineffective response policy (municipal, state and / or federal), poor organization of civil defense services and the difficulty of work involving communities in prevention activities (FERREIRA et al., 2011). Thus, beyond the perception of risk, it is necessary to understand how the people affected by these disasters engage and evaluate the effectiveness of protection and civil defense actions.

In the Amazon, major environmental disasters are more often associated with the result of severe flood events (ANDRADE and SZLAFSZTEIN, 2018) rather than as a result of extreme ebbs or droughts. This is partly due to the fact that "the biggest change in recent decades is a sharp increase in very severe flooding" (BARICHIVICH et al., 2018). In recent years, as consequence, the higher frequency of these types of extreme river events and changes in the seasonality of rivers have brought the increase in the occurrence of river environmental disasters in the state. These disasters cause numerous socio-environmental impacts, particularly severe for populations living in floodable areas.

Most studies that relate flood and ebb effects in the Amazon are focused on agricultural regions (Sternberg, 1998; Fraxe, 2000; Witkoski, 2011; Pereira, 2017; Guimaraes, 2017). However, the effects of these disasters are also felt in urban areas, as Amazonian populations have a strong relationship with water and build most of their urban centers near river banks.

Environmental disasters are the result of the use of development models that contribute to the increased social and environmental vulnerability of threats exposed to this risk. For a United Nations International Disaster Reduction Strategy (UNISDR), risk is a combination of the likelihood of an event occurring and its negative consequences and can be represented as follows (SAITO et al., 2015):

\section{$\mathrm{R}=(\mathrm{H} \times \mathrm{V}) / \mathrm{Re}$}

Where, $\mathrm{R}=$ risk; $\mathrm{H}$ = harzad; $\mathrm{V}=$ vulnerability; $\mathrm{Re}=$ response;

In the equation, the risk is inversely proportional to the responses, so the higher the response, the lower the risk. Still in this sense, even in the face of danger if there is no vulnerability, the risk will not exist. Thus, it is possible to define that the risk only exists upon the occurrence of an event with potential to harm a vulnerable community and is directly related to the responsiveness (SAITO et al., 2015).

As a way to contribute to this discussion, this article aims to unveil the perceptions of groups of residents in a precarious urbanization riverside area in the Amazon for the two types of river environmental disasters in the region: floods and extreme ebb. Perceptions were unveiled from their assessment of the dangers (hydrological factors); risks (likelihood of material and social damage); and the effectiveness of the civil protection and defense response of the public power.

\section{METHODOLOGY}

\subsection{STUDY LOCATION CHARACTERIZATION}

Cacau Pirêra is an urban district of the municipality of Iranduba, in the Brazilian Amazonas state. It is located on the right bank of the Negro River, opposite the city of Manaus on the opposite bank. The 
river port of the district is its historical landmark and allowed the beginning of settlement of the then Vila do Cacau (PINHEIRO, 2011). Since its inception, the district has been marked by the prevalence of rural versus urban characteristics.

As many families have stopped subsistence activities, money is the only way to obtain lifesustaining products. And to have access to money, residents engage in formal and informal labor market, whether in brick factories, whether as a street vendor, and other forms of work (PEREIRA and TORRES, 2012).

The municipality of Iranduba has been suffering huge socio-spatial transformations caused by urban expansion. This process was intensified after the creation of the Manaus Metropolitan Region, materialized by the construction of the bridge under Rio Negro, linking neighboring municipalities by road access to the capital Manaus (SOUZA, 2015). These changes were felt mainly in the district of Cacau Pirêra, where was previously located the main waterway port for the displacement of the municipalities of Iranduba, Manacapuru and Novo Airão to Manaus. Trade, especially of food, for people who waited considerable periods of time to make the crossing, was based on the local economy.

The weight of the economic and financial dynamics produced and reproduced as a result of the crossing from São Raimundo Port became more evident after its assignment, both for trade in the vicinity of this Manaus district and for the Cacau Pirêra district. The queues of cars and the large number of people waiting to go on the road stimulated street trading and snacking, especially on weekends, when the number of vehicles and passengers increased considerably. (SOUSA, 2013 p. 89).

The construction of the bridge under the Negro River brought to the Cacau Pirêra district the devaluation from the materialization of the fragmentation process, making this district a space with little circulation. The construction of the Rio Negro Bridge, currently called Journalist Phelippe Daou, was the main landmark of socio-spatial transformation in Cacau Pirêra. For Souza (2013), the creation of the Manaus Metropolitan Region, realized from the construction of the bridge under Rio Negro, perpetuates the logic of space production present for years in Amazonas state: concentration in Manaus, accelerated urbanization and modernization of the territory without regional development production.

The Municipal Human Development Index (MHDI) for the district of Cacau Pirêra, as well as for the whole municipality of Iranduba, is 0.613 , classified as medium development (UNDP, 2013). This evaluation should take as a unit of analysis the census tracts of the municipality and their distinctions, because in the field visits it was possible to observe the different social problems existing in the neighborhoods of the district of Cacau Pirêra, however, in the data of UNDP (2013) all census tracts of the district have the same HDI value as all other sectors of the municipality of Iranduba.

Pereira (2006) points out that at the time of the research most of the district had no electricity, asphalt and running water. In the data collection of this research it was observed that more than 10 years later the population continues with similar problems, but aggravated by the increase of population density, as well as the expansion of the territory into the rivers (Figure 2).

To collect primary data on the perception of affected people, interviews were conducted through focus groups of residents of communities affected by flood and ebb events in the Cacau Pirêra district, Iranduba / Amazonas. The communities chosen for this research were: Cidade Nova, São José and Nova Veneza (Figure 1). These communities are most severely affected by seasonal variations in the Rio Negro level of the urban area of the Cacau Pirêra District. 


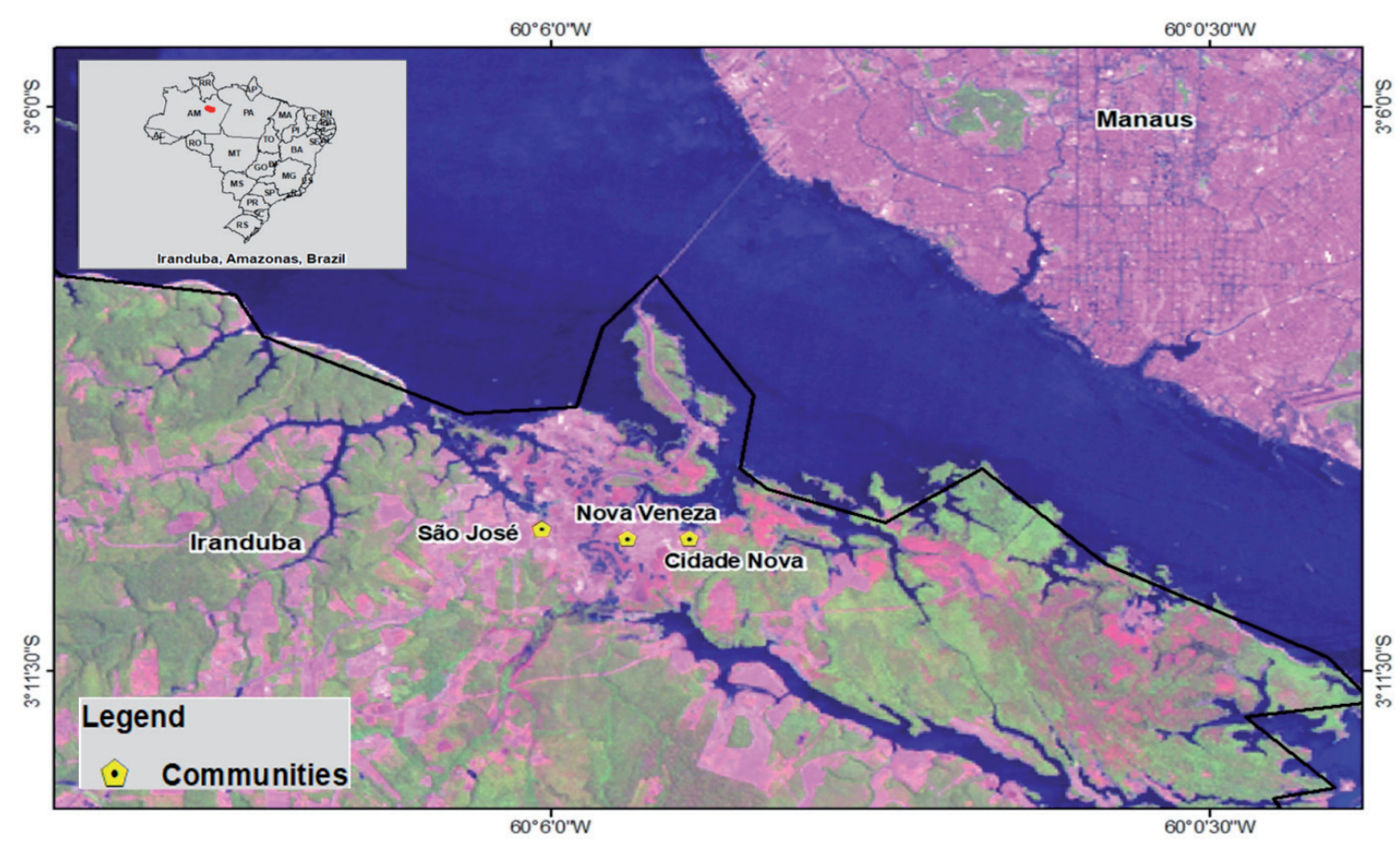

Figure 1 | Location of the Cacau Pirêra Urban Communities selected for the study.

Source: Authors.

\subsection{RISK PERCEPTION AND RESPONSE ASSESSMENT}

In this research, the dynamic interviews with focus groups aimed to elucidate the perceptions of socio environmental risks and the evaluation of protection and civil defense actions, as well as governmental and community adaptation actions against river disasters. In each community, a focus group was conducted (VAUGHN et al., 1996). Each group had a minimum of 6 and a maximum of 12 people.

During the interview, the written records of the contributions (reactions, opinions) of the focus group participants were set in a panel for viewing of all participants. The focus group was led by three researchers, one with the role of mediating the discussion and two to record the participants' contributions to tags. The focus group discussion took place in three stages. At the end of each focus group, the answers set on the panel were validated by the discussion participants.

To promote the participation of people from the affected communities, meetings were held with the board of the Cacau Pirêra Community Association, which facilitated contact and invitation to the research participants. The interviewees voluntarily participated in the research and were properly informed about its objectives. The residents signed the informed consent form. Being a research with human beings, the entire methodological procedure was forwarded to the Ethics and Research Committee of the Federal University of Amazonas - CEP / UFAM, where it was approved under the CAAE No. 73568017.4.0000.5020, of opinion No. 2,321,933.

The analysis and interpretation of the information were performed using the content analysis technique, in order to ensure greater objectivity, surpassing the superficial levels of the text (ROCHA and DEUSDARÁ, 2005). Data were organized and processed in digital spreadsheets.

The impacts caused by floods and ebb reported by focus group participants were coded and grouped according to content similarity and tabulated to record presence or absence in the response list of each focus group, thus forming a presence and absence matrix ( 1 and 0$)$. Thus, each implication could total a maximum of six (6) if it were perceived by all focus groups in both types of events. Direct field observations were made during on-site visits to the study area to complement and ascertain the information gathered from the desk research and interviews with the groups. 


\subsection{SOCIAL AND ENVIRONMENTAL VULNERABILITY AND DISASTER HAZARD}

To measure the socio environmental vulnerability, a literature review was carried out, which included the search for information in journals, books and other forms of scientific communication that addressed the socio environmental vulnerability of the Cacau Pirêra District, as well as the urbanization process that took place in this place.

For the establishment of extreme thresholds in the Cacau Pirêra District, information was collected from the flood and ebb flow quotas of the Rio Negro station located at the Manaus Waterway, obtained from the National Water Agency's HydroWeb database.

The thresholds for determining the extreme river events were calculated from the following equation (NAGHETTINI and MAURO, 2007).:

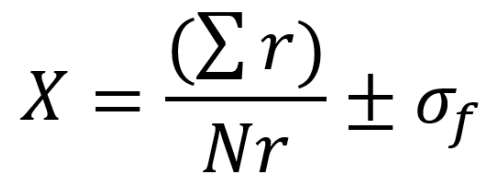

Where:

$\Sigma r$ is the sum of the records of the entire historical series of the subregion;

$\mathrm{Nr}$ is the number of records

$\sigma_{f}$ is the standard deviation

The sum was calculated in order to identify flood event thresholds and the subtraction to identify ebb extreme events. The data obtained were processed in spreadsheets to obtain descriptive statistics and the establishment of the maximum and minimum extreme thresholds. In order to compare the occurrence of extreme events with the natural disasters recognized by the Civil Protection and Defense System, data from the disaster declarations from the municipality of Iranduba were obtained from 2015 to 2017.

The altimetric map was drawn from data from the Amazon Protection System (SIPAM). The processing took place in the software QGIS 2.18., Where a heat map was consolidated to identify the different altitudes present in the land of the communities of the study area.

\section{RESULTS}

\subsection{RIVER ENVIRONMENTAL DISASTERS AS A HAZARD IN CACAU PIRÊRA DISTRICT}

The perception of environmental disasters should incorporate the physical aspects related to the occurrence of disasters. Therefore, understanding the Rio Negro river dynamics and the physical aspects of the communities is important when assessing the perceptions of the residents of riverside communities. The nearest river station to the district of Cacau Pirêra is the port of Manaus. The analysis of this station's time series allows us to identify the occurrence of extreme events (Figure 2). 


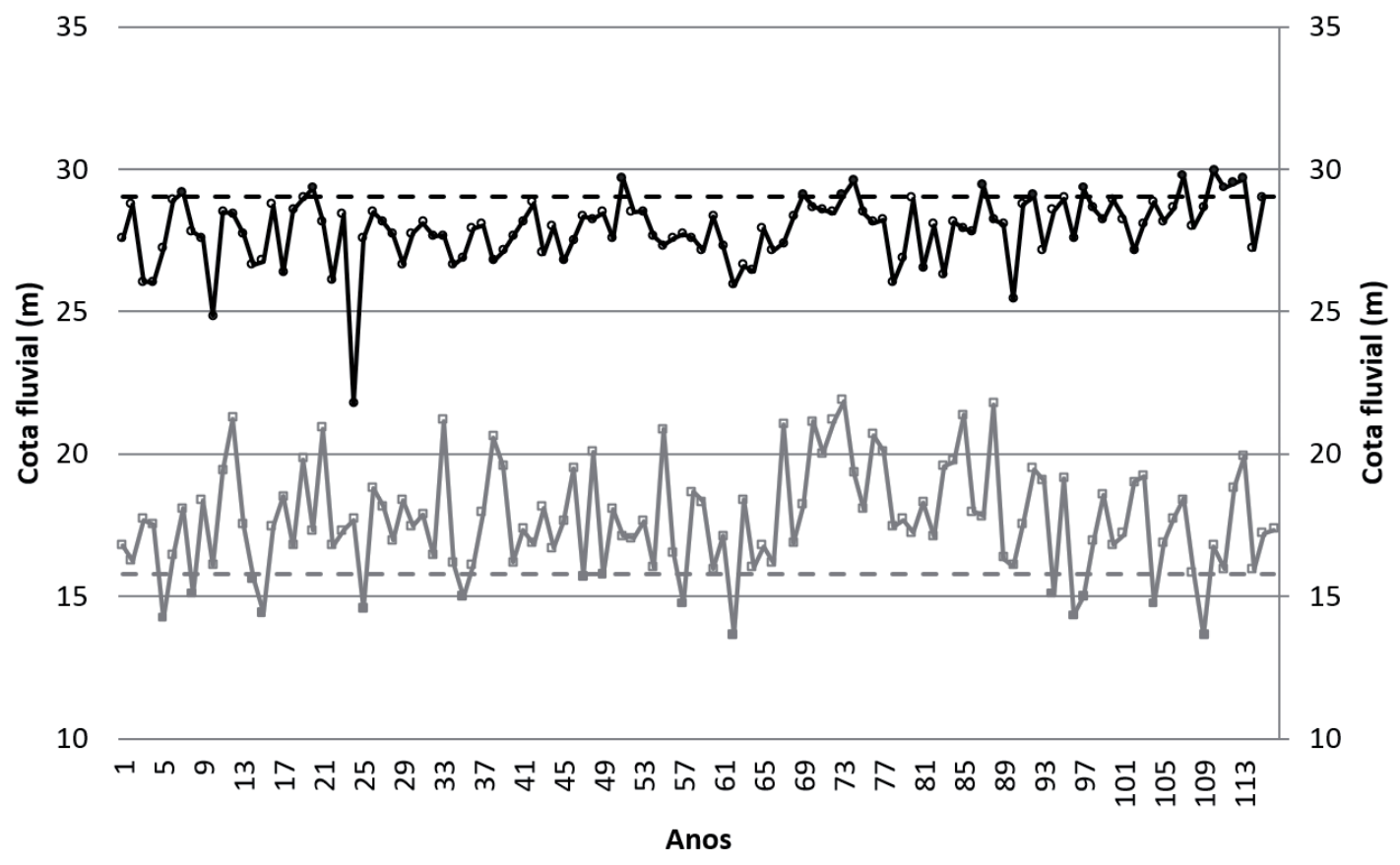

Figure 2 | Quotagram of fluviometric station of the Port of Manaus. Source: Port of Manaus (2019). Source: Authors.

The extreme flood threshold for this station was $29.03 \mathrm{~m}$ above sea level and for ebb $15.8 \mathrm{~m}$. Thus, in this station, fourteen (14) extreme river flood events and fifteen (15) ebb events were identified. From 2005 to 2017, when these events began to be classified as environmental disasters, 5 extreme river flood events and 2 flood events were accounted for.

Extreme weather events do not occur in isolation, they are part of a larger pattern, having connections with other places and on a global scale (DA SILVA DIAS, 2014). According to the IPCC (2007), climate change cannot be related to extreme events that occur in isolation, as extremes occur naturally, but the persistence of a weather pattern of these events can be attributed to climate change. of the weather.

In the Rio Negro region near Manaus, the extreme ebb events, especially those occurring in the years 2005 and 2010 (MARENGO et al., 2008; LIBERATO, 2014), caused the isolation of several riverside communities that with the shortage of their usual source of protein, especially from fishing, faced severe food and nutritional insecurity. At the opposite extreme, the region was also severely hit with extreme flood events that occurred in 2009, 2012, 2013, 2014 and 2015 (MARENGO and ESPINOZA, 2015; ESPINOZA et al., 2014) that generated major losses in several municipalities of the region.

By comparing these data with the federal recognition of the Iranduba municipal emergency or state disaster decrees, it is clear that all these extreme events identified from 2005 to 2017 were considered as disasters by the Civil Protection and Defense System. However, the 2017 flood that reached the $29 \mathrm{~m}$ quota, not exceeding this station's normal threshold, was also classified as an environmental disaster by the system. Thus, river events, even within normal limits, can be considered disasters due to the greater socio-environmental vulnerability of a given segment of the exposed population. Thus, river environmental disasters are already considered a constant harzard to the riverine communities in the Cacau Pirêra District, due to the vulnerable conditions to which these populations are already exposed. 


\subsection{SOCIAL AND ENVIRONMENTAL VULNERABILITY IN CACAU PIRÊRA DISTRICT}

For Souza (2013), the district of Cacau Pirêra goes through a process of urbanization under the domain of waters that is strongly influenced by the hydrological regime of rivers. Much of the area of the district of Cacau Pirêra, given the great extent of its river border, is located in permanent preservation areas (PPA) which considered the width of the Negro River should correspond to five hundred (500) meters from the regular bed (BRASIL, 2012).

Thus, being areas protected by forest law (Federal Law No. 12,651 / 2012), the occupation of these areas occurs irregularly. In addition to preserving resources, these areas have as one of their functions: ensuring the well-being of human populations (idem). This is because these areas are considered as sites of environmental risks, mainly related to floods and ebb. In this sense, effective management of land and environmental resources can reduce social and environmental risks (UNISDR, 2009).

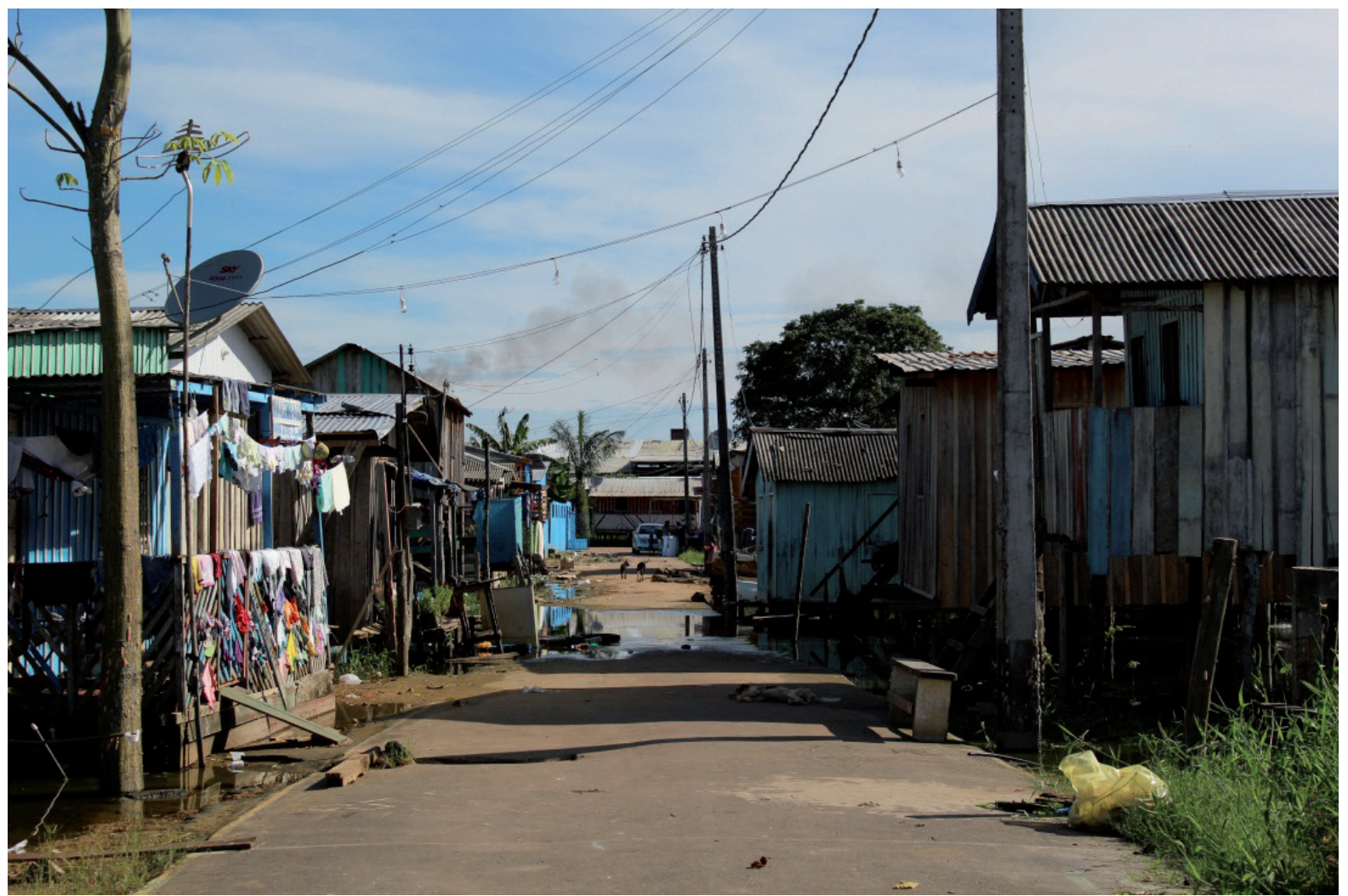

Image 1 |Overview of Cidade Nova Neighborhood in the Cacau District Pirêra. Date: June 14, 2017; Author: Guimarães (2017).

Among the factors contributing to the increased vulnerability is the altitude of the terrain where these communities are established. The Cidade Nova community occupies land with the lowest quotas in this study. This factor added to the proximity to the main riverbed generates a greater environmental vulnerability of this area. The community of Nova Veneza has the largest area of the studied communities, with the eastern part having dimensions below $16 \mathrm{~m}$. By its turn, the community of San Jose has the highest quotas among the communities analyzed, however, the expansion of the community into the river already puts part of the population prone to the risk of flooding. Thus, all the locations selected for this study have floodable areas, especially Cidade Nova and Nova Veneza, which have most of their territory in these risk areas (Figure 3 ). 


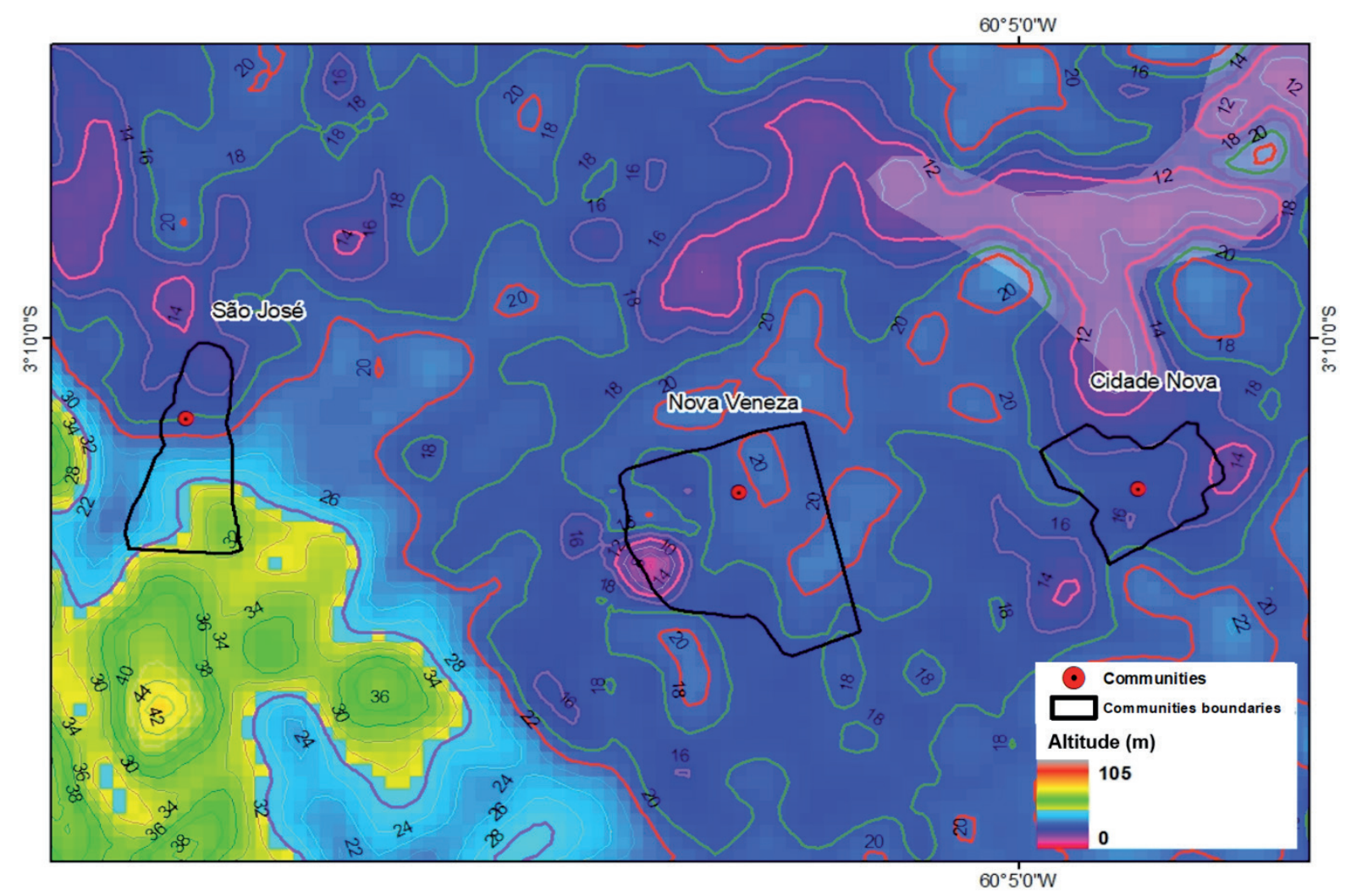

Image 3 | Altitude map of the communities studied in the district of Cacau Pirêra.

Source: Authors

In the district of Cacau Pirêra, it was found that it is not necessary that the event reaches the magnitude of extreme river hydrological event for it to be considered an environmental disaster. This is due to the very topographic characteristics of the district of Cacau Pirêra, which has a large portion of its territory made up of low altitude land.

By characterizing the district, Pereira (2006) reports a brief history of the neighborhoods studied in this research:

The Cidade Nova district is one of the oldest and closest to the left side of the harbor, just after the fair and the floating area. Part of this neighborhood is located in floodplain land, which floods partially during the flood season. The other neighborhoods are located in higher lands. Just after the New City we find the Nova Veneza subdivision. Nova Veneza is a recent area that still has no asphalt, no electricity, no running water. The neighborhoods of São José (Mutirãozinho) and Alto Nazaré (Mutirão) are located at km 2 of Estrada Manoel Urbano, being further from the Cacau Port Pirêra (PEREIRA, 2006, p. 110-111).

In Nova Veneza, as in São José, the occupation process began on higher-level land, but today a significant portion of its residents occupy similar levels to those in Cidade Nova.

Irregular occupation of PPAs results in unplanned urban growth, which accentuates processes of social exclusion, increased violence and environmental degradation, resulting in environmental disasters and other situations that cause material damage and endanger lives. (Ribeiro et al., 2011). Sometimes environmental risk areas are the only areas accessible to the lower income population, as they are very undervalued in the land market, due to risk characteristics and lack of infrastructure, a fact that overlaps risks and amplifies their effects (TORRES, 2000; ALVES, 2006). 
Irregular or illegal occupations, siltation and pollution of streams, growing violence, the demand for more services and infrastructure - such as water supply, electricity, construction of schools and health posts, among other needs. Urban equipment - These are very common situations in most Brazilian capitals. These conditions can also be observed in the small towns of the region, such as Iranduba and Manacapuru, especially because they are located closer to the great metropolis, Manaus, also end up experiencing rapid urban growth (SOUZA, 2013, p. 47).

Given its origin, vulnerability should be studied from its environmental and social constraints. Thus considered, in its double face, arises the category of social and environmental vulnerability. This new category promotes the interaction between risk situations and environmental degradation (environmental vulnerability) and situations of poverty and social deprivation (social vulnerability) (ALVES, 2006).

\subsection{THE EVALUATION OF THE PROTECTION AND CIVIL DEFENSE SYSTEM IN VIEW OF AFFECTED BY FLOOD ENVIRONMENTAL DISASTERS}

Participant assessments were categorized and grouped for quantification (Figure 4). Most of the answers are linked to the ineffectiveness of government actions in the face of natural river disasters.

In the evaluation of the participants of the three focus groups, all protection and civil defense actions employed in Cacau Pirêra are flood responses. Flood disasters are perceived by residents as having the greatest implications for the district's populations.

In the face of flood and drought disasters, the government provides assistance to affected populations through the Civil Protection and Protection System (SIPDEC). This system is present in the three spheres of government (municipal, state and federal). During the occurrences, the initial response actions are the responsibility of the municipality, which when confirmed as a situation of emergency (SE) or state of public calamity (ECP), will share the responsibility with the State and / or Federal Government (AMAZONAS, 2013).
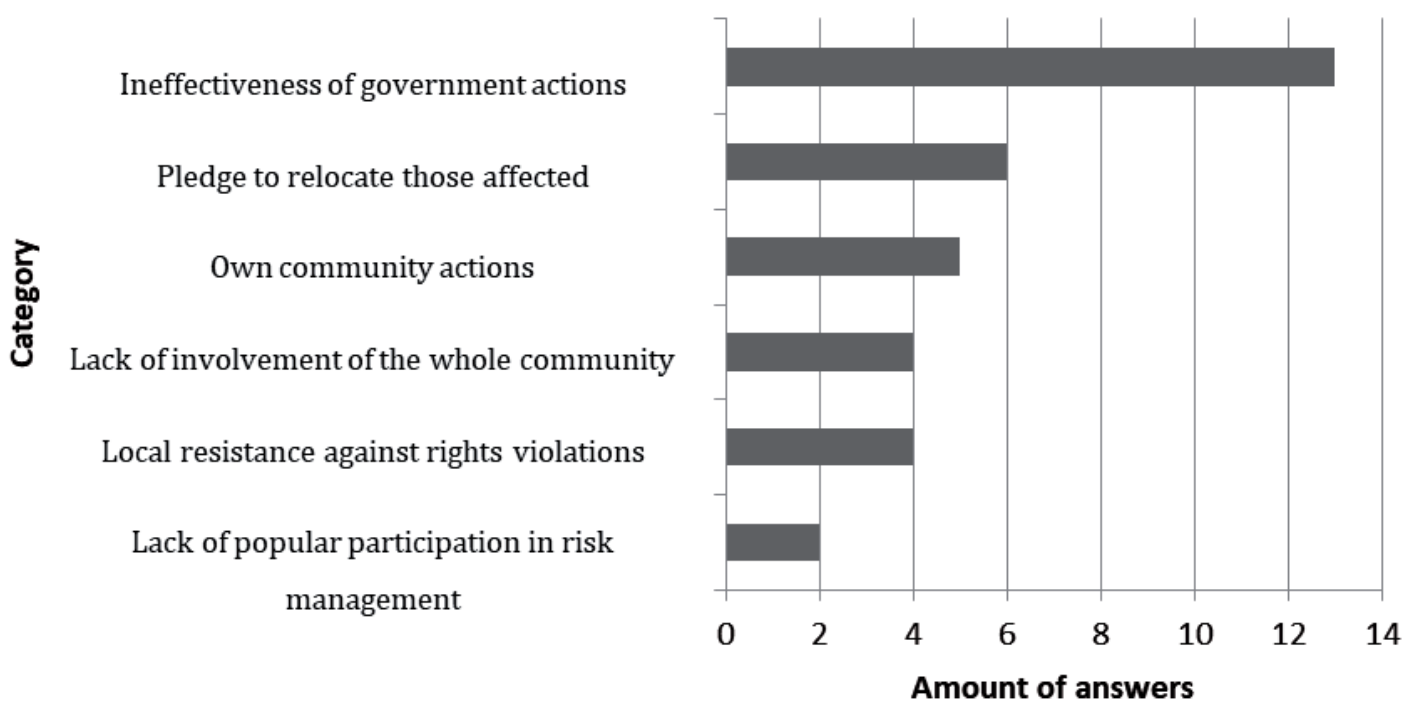

Figure 4 - Assessment of protection and civil defense actions and reactions of those affected in the face of disasters.

Source: Authors.

The ineffectiveness of protection and civil defense actions carried out in the district of Cacau Pirêra is unveiled by participants through responses such as: 
The civil defense performs the registration before the flood, but does not appear to deliver the kits to the community. Civil Defense assistance comes with the delivery of wood kits, cleaning, toilet, medicine, mattress and ranch, when it arrives in the community (Cidade Nova);

The bridges that are built do not solve the community problem and are of poor quality. The distribution of the kits in 2015 occurred after the flood occurred" (São José);

There is no delivery of kits by the civil defense in the Nova Veneza community.

In all focus groups, participants reported Civil Defense registrations in partnership with the State of Amazonas Government to relocate Cacau Pirêra communities most affected by flood disasters to other locations. However, this proposal did not materialize for most affected:

"In 2009 and 2012 [years of flood disasters] there was a promise to move to a safer place";

"[According to the people who came to make the house markings] the community cannot make house renovations after registration" (Cidade Nova);

"Accredited the houses and photographed" (Nova Veneza);

“Few residents of risk areas have been awarded My Home, My Life" (São José).

The promise of relocation of people affected by flood disasters in the district of Cacau Pirêra was also present in the participants' assessment. In all communities there were reports of housing accreditation in the Cacau District for relocation in other communities. Some participants reported that some families did not make house renovations so as not to lose the benefit. In the community of São José, participants reported that families were informed that they would receive houses in the Maria Zeneide Housing Complex, which is part of the Federal Program "Minha Casa, Minha Vida", located at UEA University City Avenue in Iranduba. However, few residents were contemplated with these residences.

Another fact linked to the ineffectiveness of Civil Defense actions is related to the types of actions taken by the agency. Residents underscore the poor quality of bridges built in flood disasters. In addition, from the participants' responses, it was possible to verify that the actions taken by the municipal protection and civil defense agency are exclusively linked to emergency responses to disasters. Thus, the action of the municipal agency continues to perpetuate a reactive view of disasters rather than planning to reduce population vulnerability. In this aspect, the major concern of the different entities of the system is predominantly related to the execution of standard procedures in the response phase linked to the coordination of the scenario and the fulfillment of bureaucratic requirements (VALENCIO, 2010).

One action taken by the community is the elevation of homes that are directly related to adaptive measures. New Venice participants reported that the estimated costs for these actions amount to $\$$ 15,000 . The "marombas" themselves, as they are called the higher provisional floors built to house furniture and appliances above the waterline, are also made from their own resources. Another perceived mobilization in the community is changing the school calendar in flood environmental disasters as school buildings also become flooded. These changes were also identified in the Newfoundland District in Careiro da Várzea (GUIMARÃES et al., 2017).

Given the ineffectiveness of protection and civil defense actions in Cacau Pirêra, the residents themselves developed a series of emergency actions of their own community in the face of flood disasters, that is, they adopted a response that can be considered autonomous adaptations (GRÜNEIS et al. 2016). situations of greater hydrological risk. 
In the emergency triggered by disasters, local populations and their organizations mobilize to respond and try to reduce the risks of these events themselves. With the lack of river ambulances at the district health post, community members themselves organize to take residents to emergency medical care in floods. Some local organizations mobilize to provide humanitarian aid to these populations, such as the Catholic Church, through the Sant'Ana Community. Another type of action carried out by community members is the adaptation of homes to the higher frequency of flooding (Image 2). In order to resist flood events, residents tend to raise the floor height of their homes.

While participants acknowledge the omission and lack of community involvement in rights enforcement actions, they report the resilience of local populations against the violation of the rights of people affected by disasters. Participants in New Venice reported that "few community members make charges," in Cidade Nova participants also reported that "there is no community engagement". The poor adherence of the community to the movements and claims may have to do with the fact that they no longer believe in the transformations of their realities in the face of all the mismatches of the public power with the community.

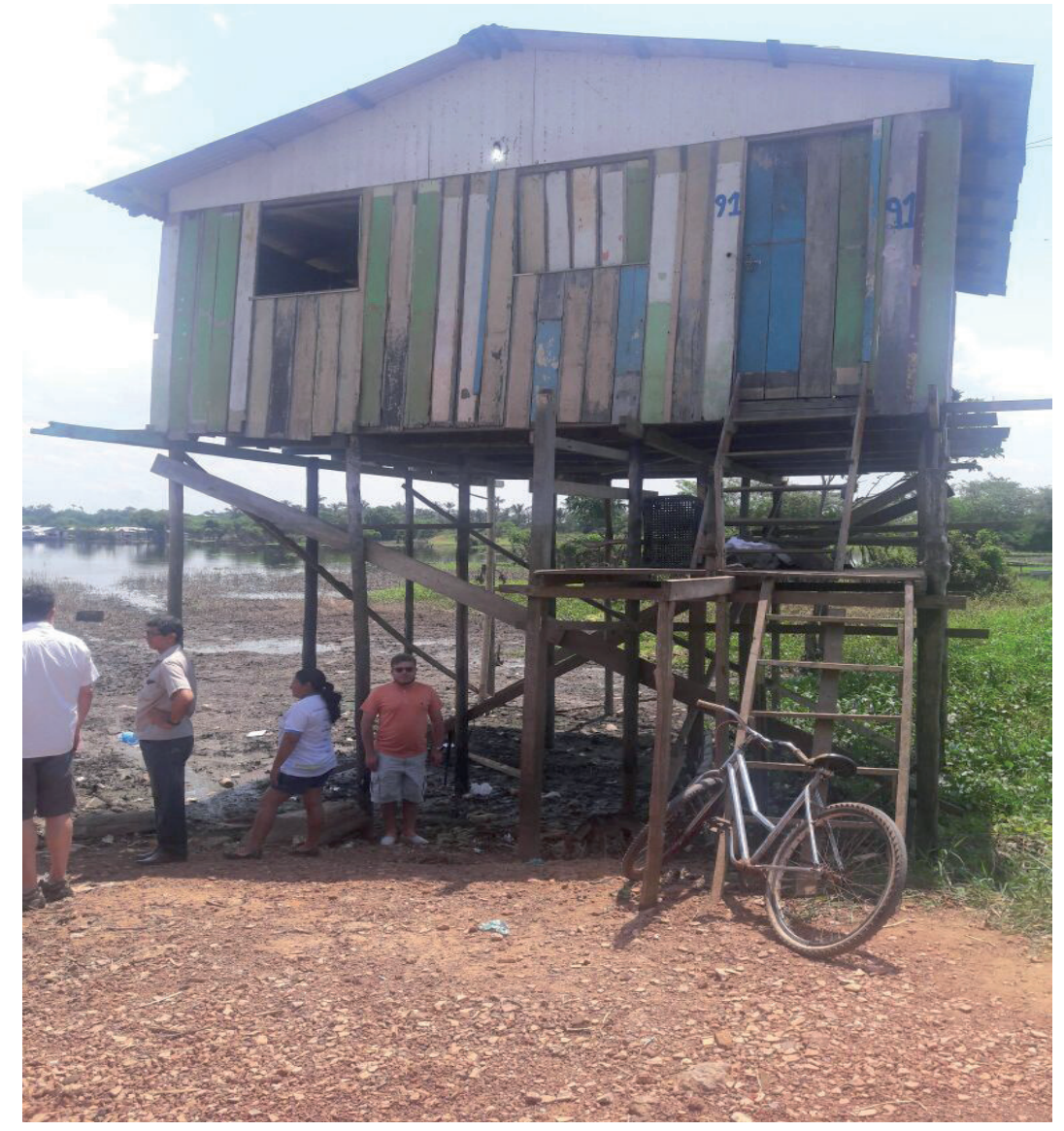

Image 2 | Stilt house in the Cidade Nova community. Date: October 16, 2017. Author: Guimarães (2017).

However, at the same time, the affected residents present several initiatives that arise in their own community to address the various violations of rights, elucidated in some lines: "There is the claim of residents for the guarantee of rights" and "the community conducts demonstrations". The work of local organizations such as the Pirêra Cacau Community Association, Jasmin Women's Association and the Cacau Pirêra Political Emancipation Movement reveal that the struggle for the guarantee of collective rights in this district are clear signs of resistance and mobilization for environmental justice (ACSELRAD, 2015). These movements have already mobilized the district to hold demonstrations and settle other formal political spaces, such as public hearings, rights and public policy councils, and other social projects for communities. 
One of these events took place in 2017, which, among its guidelines, brought the lack of actions by the municipal government in the face of flood environmental disasters (Image 3 ).

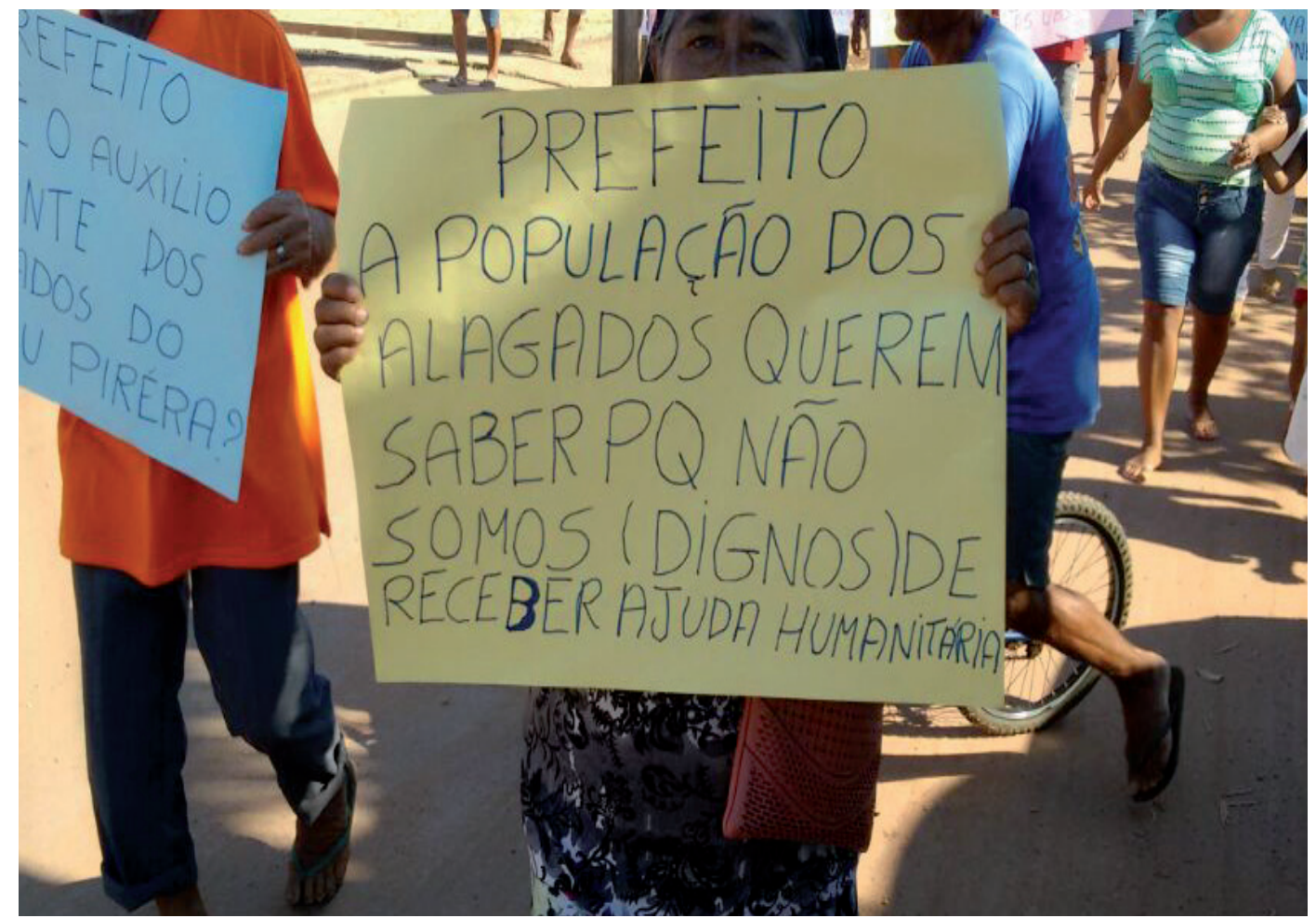

Image 3 | Demonstration in those of Cacau Pirêra district, Iranduba / Amazonas. Date: June 23, 2017;

Author: Guimarães (2017). (text in the image reads: "Mayor / The population of the flooded areas want to know why we are not (worthy) of receive humanitarian aid").

The indignation of the population with the ineffectiveness of public agencies is also explained in their perception of the lack of popular participation in risk management in the municipality of Iranduba. This assessment is due, according to the participants, to the lack of communication with the Civil Defense that does not have spaces of direct communication with the community or their integration in the risk management processes.

The lack of communication spaces and the low participation of residents in risk management in the Cacau Pirêra District reveal a still reactive and technical activity of public agencies in disaster management. When a civil defense action is guided by the technical approach, civil defense agents are related to the occurrence of disasters with ignorance of affected people, basing their work on the logic that the population should be informed about local risks, disregarding social and environmental inequalities, founding factors of this process (VALENCIO, 2010). Thus, a technical approach:

"[...] reinforces the process of vulnerability, that is, the sociopolitical relationship of violence that undermines the rights of the other and, in the midst of which, the welfare project on the part of the nation is nourished by the discomfort caused to the remaining" (VALÊNCIO, 2014).

The practice of blaming those affected by the occurrence of environmental disasters is a defensive and misleading discourse that reflects the neglect of public power organizations and society in addressing the social and environmental degradation to which affected populations are subjected. To blame them for the situation of vulnerability because of their sociocultural characteristics that involve their permanence in these areas is to reproduce the notion that social inequality, as well as flooding, is a "natural" fact and not produced by society. 
The ineffectiveness of public action also results from the low responsiveness of the local system aggravated by the weakening of Iranduba's Municipal Coordination of Protection and Civil Defense physical and human structure. It has only five employees on its staff to serve the entire municipality of Iranduba. The municipal executive has not yet understood the importance of strengthening efforts to reduce the environmental risks of the population through protection and civil defense actions.

Thus, a precautionary approach to managing these river disasters requires effective action that reduces the socio-environmental vulnerabilities of at-risk populations in the Cacau Pirêra District.

There is a need for changes in socioecological systems that lead people to a new standard of quality of life, with the provision of public services and urban infrastructure appropriate to the conditions of greatest hydrological risk. The guarantee of increased resilience of these populations emerges as one of the means to achieve sustainability (VEIGA, 2014).

To this end, governments should invest more in cross-cutting adaptation strategies to minimize the impacts of flood and drought natural disasters. Still, public investments for the adaptation of human communities in the Amazon are still practically nil, even recognizing the importance of protecting this biome (MAY and VINHA, 2012), as well as the intensification of extremes of the Amazon river flow caused by climate change. (IPCC, 2014).

For Pinheiro (2011), the district of Cacau Pirêra represents in many ways a reality of extreme social inequality that lives the various Amazonian interiors. Addressing socio-environmental vulnerabilities would result from governance strategies with effective and active participation of vulnerable populations in formal political spaces (PORTO, 2011).

\subsection{RISK PERCEPTION TO RIVER ENVIRONMENTAL DISASTERS}

In addition to the vulnerability determined by physical factors, it is necessary to understand the socioenvironmental implications to which populations are exposed as a result of river disasters. In this sense, participants perceive a series of socio-environmental implications inherent in flooding.

The main difficulties evidenced by the participants were the difficulty of mobility, increased school dropout, lack of civil defense responses and increased animal attack. These difficulties were perceived by participants in the three focus groups for both flood and extreme ebb disasters.

In flood disasters, population mobility is compromised, and people often have to travel within the river or ask for help from neighbors who have canoes to make their mobility. In the focus group of the Cidade Nova community, the following report highlights this situation:

When the flood is very big and we have to go to work, we take our clothes in a bag, get in the water and change clothes as soon as we arrive on dry land in a public toilet or in someone's house. known.

Extreme hydrological river events of ebb and flow generate disturbances for the displacement of students from schools in riverside communities in the Amazon region (GLÓRIA, 2012, p.33; GUIMARÃES et al., 2017). In the urban district of Cacau Pirêra, the increase in school dropout seems to be linked only to the occurrence of flooding periods. In floods, due to lack of resources and as a way to prevent accidents, such as drowning children, also perceived by participants, many parents do not allow younger children to attend classes. Another danger perceived by participants was the attack of venomous and dangerous animals such as snakes and scorpions, and even alligators, reported by participants as common during this period. 
Civil Defense against flood disasters in the Cacau Pirêra District. They report that each year, although records of people living in flooded areas are recurring, humanitarian aid kits are not delivered to affected populations in the district on a recurring basis.

In two communities, participants reported more intense flooding in recent years where disasters occurred. In the Cidade Nova community, closer to the main riverbed, the damage caused by floods in flood disasters has been reported. Damage to the structure of homes and to furniture and appliances hit by the flood were cited.

In the community of Nova Veneza, participants reported difficulties in fishing due to flooding. In two communities, New Town and New Venice, increased theft has been reported. These crimes occur in floods, because some community members rent or go to family homes to avoid suffering the major impacts of these disasters and end up having their homes violated and stolen. The increased violence in the District may be associated with the process of conurbation that has intensified in recent years, with the construction of the bridge under the Rio Negro that connects Manaus, the state capital, to the municipalities of Iranduba and Manacapuru (SOUZA, 2013, p. 180).

Even though a significant part of the implications perceived by participants is not exclusively linked to flood disasters, the absence of state basic services tends to potentiate the effects of river environmental disasters, generating more social suffering for populations living in risk areas. This fact reveals the process of environmental injustice that these populations live. Therefore, in addition to being vulnerable, these social groups are vulnerable by the denial of their basic rights (ACSELRAD, 2015).

For Porto (2011), people in vulnerable situations already experience a "daily disaster" amidst precarious living conditions, which can be intensified in the occurrence of environmental disasters.

Drinking water supply in the district of Cacau Pirêra is poorly functioning and worsens in the presence of flooding events, as the pipeline is submerged, causing the population to use the water from the river itself, which is contaminated by sanitary sewage from homes. Health problems resulting from contamination of water by urban waste and vectors exult in the high rate of waterborne diseases such as leptospirosis, viral hepatitis, diarrheal diseases, etc. (BRAZIL, 2012b; BARCELLOS et al., 2009).

The unique dangers of extreme ebb disasters are poorly understood by participants. The main social and environmental implications perceived in the research in the communities of São José and Cidade Nova were the burning. Smoke pollution may result in the development of respiratory diseases, as reported in São José. In the Cidade Nova community, participants pointed to the increased risk of river trips during the ebb due to the formation of sandbanks in the river courses.

The implications related to ebb may not be so perceived by the participants by their non-exclusive dependence on surface waters. Being a district with markedly urban characteristics, residents do not have as their main activities hunting, fishing and not even use the rivers as the main way of moving to other places.

Some implications are linked to both flood and ebb events. In both flood and ebb disasters, the most cited socio-environmental implications were the absence of actions by the public authorities regarding the access and quality of public environmental sanitation and public transport services, mainly.

Another important implication mentioned in the groups was the presence of waterborne diseases, especially in flood disasters. These diseases are directly related to other responses provided by participants, such as lack of sanitation, inadequate disposal of solid waste and other sources of pollution, which were perceived as inherent implications of flooding by all groups, as well as lack of water. drinking According to the participants, these diseases mainly affect children who have symptoms of vomiting and diarrhea. 
The difficulty of river transport was also remembered by the participants. In all groups this implication was remembered as linked to flooding. Only the community of Nova Veneza related the difficulty of transportation also with the ebb events. Despite the existence of a bridge over the Negro river, the population of the district often uses the fast boat river transportation carried out by a transport cooperative. The presence of strong ebbs prevents vessels from reaching the port, and it is necessary to move the embarkation and disembarkation to other locations and charter a minibus to transfer passengers from Cacau port to this provisional location.

When comparing the amount of socio environmental implications per community, in Nova Veneza participants presented a greater number of socio environmental problems, twenty-two (22), most of them sixteen (16), related to flooding. However, the community that most perceived the socioenvironmental implications of the ebb disasters was Cidade Nova with the perception of eight (8) socio-environmental implications in these events.

Analyzing the amount of implications related to both types of disasters, it is clear that participants feel more strongly those related to floods, thirty-nine (39) indications, than those of ebb, 18 (18). Thus, floods are perceived as the most dangerous river environmental disasters in Cacau Pirêra.

\section{FINAL CONSIDERATIONS}

The effects of global warming are already beginning to be felt by riverine populations, through the higher frequency of extreme river events and other events close to the normal thresholds that end up generating river environmental disasters.

In the Cacau Pirêra District, already weakened by fragmentation processes and marked by the ineffectiveness of government actions, river environmental disasters end up potentiating the socioenvironmental vulnerabilities existing in this territory. Flood disasters have more socio environmental implications for communities in the district than for floods.

In the midst of existing vulnerabilities in the District, resistance from communities as a means of addressing local social and environmental problems is an important aspect of gaining rights with and for these populations. Public authorities should consider the participation of representatives of Cacau Pirêra organizations and elsewhere in participatory governance processes in risk management.

Due to climate change, an increase in the frequency and intensity of floods and extreme ebbs in the Amazon is expected, resulting in a future scenario of increased risk of river disasters. In this context, the planning and implementation of public policy adaptation actions for both rural and urban riverine populations, as a matter of urgency, respecting their specificities and understanding the complexity of factors that make them vulnerable, become urgent.

Given the high socio environmental vulnerability that the population of the Cacau Pirêra District has, potentiated by the danger of drought and flood river environmental disasters in the region and added by the absence or ineffectiveness of the public power responses we can conclude that there is a high social and environmental risk existing in this location. Therefore, there is a need to think about structural and structuring strategies for disaster risk management in this district and other riverside communities exposed to the same conditions.

When studying the river environmental disasters in the Amazon region, it is not possible to analyze the process of occupation and vulnerability of the riverside communities in isolation. It is necessary to understand that river environmental disasters raise issues that encompass the environmental and social dimensions, ie the whole socio-ecological system. The pursuit of the objectives of sustainable development in the Amazon requires adaptation to climate change, which requires interdisciplinary knowledge from dialogues between 
the earth and atmosphere, bio-ecological, social, political and economic sciences, and that these goals are present in local political agendas. and regional. Therefore, broader studies are crucial to think about structural and structural adaptive strategies for the riverside populations of these vulnerable areas.

\section{REFERENCES}

ACSELRAD, H. Vulnerabilidade social, conflitos ambientais e regulação urbana. O Social em Questão-Ano XVIII, n. 33, 2015.

ALVES, H. P. da F. Vulnerabilidade socioambiental na metrópole paulistana. Revista brasileira de estudos populacionais, São Paulo, v. 23, n. 1, p. 43-59, jan./jun., 2006.

AMAZONAS (DEFESA CIVIL). Riscos e Desastres Naturais em Manaus. 2013. 33 f.

ANDRADE, M. M. N., SZLAFSZTEIN, C. F. Vulnerability assessment including tangible and intangible components in the index composition: An Amazon case study of flooding and flash flooding. Science of The Total Environment, v. 630, p. 903-912, 2018. https://doi.org/10.1016/j.scitotenv.2018.02.271.

BARCELLOS, C. et al. Mudanças climáticas e ambientais e as doenças infecciosas: cenários e incertezas para o Brasil. Epidemiologia e Serviços de Saúde, v. 18, n. 3, p. 285-304, 2009.

BARICHIVICH, Jonathan et al. Recent intensification of Amazon flooding extremes driven by strengthened Walker circulation. Science advances, v. 4, n. 9, p. eaat8785, 2018.

BRASIL. Decreto № 7.257, de 4 de agosto de 2010. Regulamenta a Medida Provisória no 494 de 2 de julho de 2010, para dispor sobre o Sistema Nacional de Defesa Civil - SINDEC, sobre o reconhecimento de situação de emergência e estado de calamidade pública, sobre as transferências de recursos para ações de socorro, assistência às vítimas, restabelecimento de serviços essenciais e reconstrução nas áreas atingidas por desastre, e dá outras providências. Congresso Nacional: Brasília. 2010.

BRASIL. Lei 12.652, de 25 de maio de 2012. Dispõe sobre a proteção da vegetação nativa; altera as Leis nos 6.938, de 31 de agosto de 1981, 9.393, de 19 de dezembro de 1996, e 11.428, de 22 de dezembro de 2006; revoga as Leis nos 4.771, de 15 de setembro de 1965, e 7.754, de 14 de abril de 1989, e a Medida Provisória no 2.166-67, de 24 de agosto de 2001; e dá outras providências. Congresso Nacional: Brasília. 2012.

BRASIL. Ministério da Integração Nacional. Secretaria Nacional de Defesa Civil. Centro Nacional de Gerenciamento de Riscos e Desastres. Anuário brasileiro de desastres naturais: 2012 / Centro Nacional de Gerenciamento de Riscos e Desastres. - Brasília: CENAD, 2012b.

COÊLHO, A. E. L. Percepção de risco no contexto da seca: um estudo exploratório. Psicologia para América Latina, n. 10, 2007.

DA SILVA DIAS, M. Assunção Faus. Eventos climáticos extremos. Revista USP, n. 103, p. 33-40, 2014.

Espinoza JC, Marengo JA, Ronchail J, Molina J, Noriega L, Guyot JL. The extreme 2014 flood in South-Western Amazon basin: the role of tropical-subtropical South Atlantic SST gradient. Environ. Res. Lett. 9: 124007, doi: 10.1088/1748-9326/9/12/124007. 2014.

FERREIRA, D., ALBINO, L. FREITAS, M. J. C. C. Participação popular na prevenção e enfrentamento de desastres ambientais: resultado de um estudo piloto em Santa Catarina, Brasil. Revista Geográfica de América Central, 2(47E):1-17. 2011. 
FRAXE, T.J.P. Homens anfíbios: etnografia de um campesinato das águas. São Paulo Annablume; Fortaleza: Secretaria de Desporto do Governo do Estado do Ceará. 192p. 2000.

GLÓRIA, S. A. Estudos hidrológicos como subsídio para a melhoria do acesso dos alunos do ensino fundamental às escolas ribeirinhas na bacia do Tarumã-mirim, Manaus/AM. 107 f. Dissertação (Mestrado em Geografia) Universidade Federal do Amazonas. 2012.

GUIMARÃES, D. F. S.; PEREIRA. H. P.; VASCONCELOS, M. A.; SILVA, S. C. P.; NASCIMENTO, A. C. L.; SILVA, M. A. P. Os impactos dos eventos extremos na assiduidade dos alunos no distrito de Terra Nova, Careiro da Várzea/AM. In: ENANPPAS 2017 - VIII Encontro Nacional da Associação Nacional de Pós-Graduação e Pesquisa em Ambiente e Sociedade. Natal, RN. 2017. Disponível: http://icongresso.anppas.itarget.com.br/anais/index/resultado/index/ index/cc/2. Acessado em: 25 jan. 2018.

HO, M., SHAW, D., LIN, S., CHIU, Y. How Do Disaster Characteristics Influence Risk Perception?. Risk Analysis, 28 (3): 635-643. 2008. doi:10.1111/j.1539-6924.2008.01040.x

HUMMELL, B. M.L., CUTTER, S. L., EMRICH, C.T. Social Vulnerability to Natural Hazards in Brazil. Int J Disaster Risk Sci, 7 (2) : 111. 2016. https://doi.org/10.1007/s13753-016-0090-9.

Intergovernmental Panel on Climate Change (IPCC). Climate Change 2014: Impacts, Adaptation, and Vulnerability. Part B: Regional Aspects. Contribution of Working Group II to the Fifth Assessment Report of the Intergovernmental Panel on Climate Change. 2014.

Intergovernmental Panel on Climate Change (IPCC). Climate Change, 2007: the physical science basis (summary for policymakers). Gênova: IPCC Secretariat, 2007. 18p.

International Strategy for Disaster Risk Reduction - UNISDR. UNISDR terminology on disaster risk reduction. Geneva. 2009. Acesso em: 12 de jan. 2017. Disponível em: <http://www. unisdr.org/eng/terminology/ terminology-2009-eng.html>.

LIBERATO, A. M. Estudo de Eventos Climáticos Extremos na Amazônia Ocidental e seus Impactos na Hidrovia Rio Madeira. Tese (Doutorado em Meteorologia) - Universidade Federal de Campina grande. Campina Grande, 2014. Disponível em:

http://dca.ufcg.edu.br/posgrad_met/teses/AiltonMarculinoLiberato_2014.pdf. Acessado em: 05 jan. 2018.

MARENGO J.A., Nobre C.A., Tomasella J., Cardoso M.F., Oyama M.D. Hydro-Climatic and Ecological Behaviour of the Drought of Amazonia in 2005. Philosophical Transactions of The Royal Society, 363:1773-1778. 2008.

MARENGO, José Antonio; ESPINOZA, J. C. Extreme seasonal droughts and floods in Amazonia: causes, trends and impacts. International Journal of Climatology, v. 36, n. 3, p. 1033-1050, 2016.

MATTEDI, M. Dilemas e perspectivas da abordagem sociológica dos desastres naturais. Tempo Social, vol. 29 (3), 2017. Disponível em https://www.revistas.usp.br/ts/article/view/111685. Acesso em: 11 mar. 2019.

MAY, P. H. VINHA, V. da. Adaptação às mudanças climáticas no Brasil: o papel do investimento privado. Estudos Avançados, vol. 26 (74), 2012.

NAGHETTINI, Mauro; PINTO, Éber José de Andrade. Hidrologia estatística. CPRM, 2007.

PEREIRA, H. A. Fronteiras da vida: o tradicional e o moderno no Cacau Pirêra/Iranduba - Manaus: UFAM, 2006. 201 f.; il. 
PEREIRA, H.; TORRES, I. C. A imagem da cidade: cotidiano, sonhos e utopias dos moradores do Cacau PirêraIranduba (AM). Somanlu: Revista de Estudos Amazônicos, [S.I.], v. 8, n. 1, p. p. 25-42, jun. 2012. ISSN 2316-4123. Disponível em: <http://www.periodicos.ufam.edu.br/somanlu/article/view/317>. Acesso em: 27 fev. 2018. doi: https://doi.org/10.17563/somanlu.v8i1.317.

PEREIRA. H. P.; VASCONCElOS, M. A.; GUIMARÃES, D. F. S.; SILVA, S. C. P.; NASCIMENTO, A. C. L.; SILVA, M. A. P. Mortandade de espécies arbóreas causadas por eventos climáticos extremos em áreas inundáveis da Amazônia Central. In: ENANPPAS 2017 - VIII Encontro Nacional da Associação Nacional de Pós-Graduação e Pesquisa em Ambiente e Sociedade. Natal, RN. 2017. Disponível: http://icongresso.anppas.itarget.com.br/anais/index/ resultado/index/index/cc/2. Acessado em: 25 de jan. 2018.

PINHEIRO, H. A. POLÍTICAS PÚBLICAS, URBANIZAÇÃO E DESENVOLVIMENTO NA AMAZÔNIA. In: V Jornada Internacional de Políticas Públicas. 23 a 26 de agosto de 2011. São Luís. 2011. Disponível em: http:// www.joinpp.ufma.br/jornadas/joinpp2011/CdVjornada/JORNADA_EIXO_2011/QUESTAO_AMBIENTAL_ DESENVOLVIMENTO_E_POLITICAS_PUBLICAS/POLITICAS_PUBLICAS_URBANIZACAO_E_DESENVOLVIMENTO_ NA_AMAZONIA.pdf. Acessado em: 02 jan. 2018.

PNUD. Programa das Nações Unidas para o Desenvolvimento. ATLAS Brasil. Atlas do Desenvolvimento Humano no Brasil. 2013. Disponível em: http://www.br.undp.org/content/dam/brazil/docs/IDH/undp-br-rankingidhm-2010.pdf. Acesso: 30 jan. de 2018.

PORTO DE MANAUS. Níveis Máximo e mínimo. https://www.portodemanaus.com.br/?pagina=niveis-maximominimo-do-rio-negro. 2019.

PORTO, M. F. de S. Complexidade, processos de vulnerabilização e justiça ambiental: um ensaio de epistemologia política. Revista crítica de ciências sociais, n. 93, p. 31-58, 2011.

RIBEIRO, A. S., do AMARAL, F. O. M., SILVA, J. M., Jr, COSTA, L. A., \& OlIVEIRA, V. F. M. In A. S. Ribeiro (Coord.), Cidade Sustentável, bem-estar para todos: uso e ocupação do solo e seus impactos ambientais (p. 25). Palmas: Ministério Público do Estado do Tocantins. 2011. Disponível em: <https://athenas.mpto.mp.br//athenas/CMS/ download/2014/01/20/cartilha-cidade-sustentavel/>. Acessado em: 18 de jan. 2017.

ROCHA, D.; DEUSDARÁ, B. Análise de Conteúdo e Análise do discurso: aproximações e afastamentos na (re) construção de uma trajetória. Revista ALEA. Rio de Janeiro, v. 7, n. 2, p. 305-322, 2005.

ROSA, T. S. MALUF, R. Populações vulnerabilizadas e o enfrentamento de eventos climáticos extremos: estratégias de adaptação e de mitigação. Boletim da sociedade de economia ecológica. Edição especial, no 23/24. Jan-Ago, 2010.

SAITO, S. M.; SORIANO, E.; LONDE, L. de. R. Desastres naturais. In: SAUSEN, T. M.; LACRUZ, M. S. P. Sensoriamento Remoto para desastres. São Paulo: Oficina de textos, 2015.

SOUSA, Isaque dos Santos. A ponte Rio Negro e a Região Metropolitana de Manaus: adequações no espaço urbano-regional à reprodução do capital. 2013. Tese de Doutorado. Universidade de São Paulo.

SOUZA, I. S. Estado e capital na reestruturação da borda sul da Região Metropolitana de Manaus. In: Schor, Tatiana e Santana, Paola Verri. (Org.). Dinâmica Urbana na Amazônia Brasileira. 1ed. Manaus: Valer, CNPq, Fapeam, 2015, v. II, p. 39-58.

STERNBERG, H. O. R. A Água e o Homem na Várzea do Careiro. Museu Paraense Emílio Goeldi. Belém. 1998.

TORRES, H.G. A demografia do risco ambiental. In: TORRES, H.G. e COSTA, H. (Org.). População e meio ambiente: debates e desafios. São Paulo: Senac, 2000. p. 53-73. 
VALÊNCIO, N. F. L. da S. Disasters: technicism and social suffering. Ciência \& Saúde Coletiva, v. 19, n. 9, p. 36313644, 2014.

VALÊNCIO, Norma. Desastres, ordem social e planejamento em defesa civil: o contexto brasileiro. Saúde e Sociedade, v. 19, n. 4, p. 748-762, 2010.

VAUGHN, S.; SCHUMM, J. S.; SINAGUB, J. Focus group interviews in education and psychology. California: Sage Publications. 1996. 174 p.

VEIGA, J. E. O âmago da sustentabilidade. In: Estudos Avançados, v. 28 (82), p. 7-23, 2014.

WITKOSKI, A. C. Terras, florestas e águas de trabalho: os camponeses amazônicos e as formas de uso de seus recursos naturais. São Paulo: Annablume, 2010. 